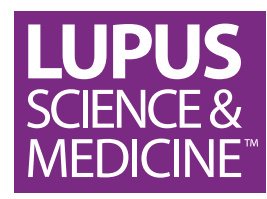

\title{
Dynamics of pulse wave velocity and vascular augmentation index in association with endothelial progenitor cells in SLE
}

\author{
Peter Korsten, ${ }^{1}$ Daniel Patschan, ${ }^{1}$ Elvira Henze, ${ }^{1}$ Timothy B Niewold, ${ }^{2}$ \\ Gerhard Anton Müller, ${ }^{1}$ Susann Patschan ${ }^{1}$
}

To cite: Korsten $P$, Patschan D, Henze E, et al. Dynamics of pulse wave velocity and vascular augmentation index in association with endothelial progenitor cells in SLE. Lupus Science \& Medicine 2016:3:e000185. doi:10.1136/lupus-2016000185

Received 18 August 2016 Revised 11 October 2016 Accepted 26 October 2016

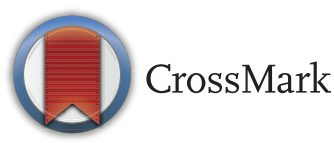

${ }^{1}$ Department of Nephrology
and Rheumatology,
University Medicine
Göttingen, Göttingen,
Germany
${ }^{2}$ Department of
Rheumatology, Mayo Clinic,
Rochester, Minnesota, USA

Correspondence to

Professor Daniel Patschan; d.patschan@gmail.com

\section{ABSTRACT}

Patients with SLE display a significantly higher cardiovascular risk (CVR). Pulse wave velocity (PWV) has meanwhile been established as a reliable parameter of end-organ damage. Endothelial progenitor cells (EPCS) are critically involved in vascular repair under both physiological and pathological conditions. The aim of the study was to analyse PWV and the Vascular Augmentation Index (VAI) and EPC numbers/ regeneration in a well-defined German SLE cohort. Thirty patients were included. Only two individuals displayed a PWV of above $10 \mathrm{~m} / \mathrm{s}$. There was no correlation between PWV percentiles and disease activity as reflected by the SLE Disease Activity Index. Neither EPC colonies nor percentages of circulating EPCs (CD133+/KDR+) correlated with PWV/NAI in a positive or negative manner. Thus, it can be questioned whether pulse wave analysis and/or EPC proliferation and circulating cell numbers are truly useful for CVR assessment in SLE.

Patients with SLE have a prevalence of cardiovascular disease up to 50 times higher than healthy individuals. ${ }^{1}$ Recently, we were able to show that regeneration of endothelial progenitor cells (EPCs) may be impaired in SLE. ${ }^{2}$ Aortic pulse wave velocity (PWV) measurement and the central Vascular Augmentation Index (VAI) serve as surrogate markers for arterial stiffness. They represent independent predictors of cardiovascular structural damage and correlate with clinical outcomes. ${ }^{3}{ }^{4}$ The aim of this study was to correlate parameters of vascular stiffness with EPC regeneration/circulating EPCs in a welldefined German SLE cohort. The patients were consecutively recruited from the Clinic of Nephrology and Rheumatology of the University Hospital of Göttingen. Prevalences of the following comorbidities were arterial hypertension, $61 \%$; smoking, $26 \%$; use of steroids, $82 \%$ and statin therapy, $13 \%$ (table 1 ).
Analysis of PWV and VAI were successfully performed in 23 of 30 patients. All patients signed written consent to participate. The mean PWV was $6.4 \pm 1.7 \mathrm{~m} / \mathrm{s}$ in all patients. Only two individuals displayed a PWV of above $10 \mathrm{~m} / \mathrm{s} \quad(10.4$ and $11.3 \mathrm{~m} / \mathrm{s})$. PWV positively correlated with age $(p=0.024)$. There was no correlation between PWV percentiles and disease activity as reflected by the SLE Disease Activity Index. The latter did also not correlate with the VAI percentiles, but anti-double stranded DNA levels correlated with the augmentation index in a negative manner (correlation coefficient $-0.46, p=0.029)$. Neither EPC colonies nor percentages of circulating EPCs (CD133 + / KDR+) correlated with PWV/VAI in a positive or negative manner (figure 1).

The most intriguing result of the current investigation was related to the absolute PWV values in patients with SLE with only two individuals displaying a PWV of above $10 \mathrm{~m} / \mathrm{s}$. A PWV of above $10 \mathrm{~m} / \mathrm{s}$ has meanwhile been accepted as marker of cardiovascular end-organ damage. ${ }^{5}$ Castejon $e t a t^{6}$ reported a mean PWV in SLE of $7.8 \pm 2.2 \mathrm{~m} / \mathrm{s}$ with lower percentages of circulating EPCs in those patients displaying pathological PWV values. Nevertheless, the absolute range of PWV values in this particular category was not mentioned in the study. Comparable data have been reported by Valero-Gonzalez but once again, the absolute range of values is missing. ${ }^{7}$ A very early investigation was published in 2001, evaluating PWV in female patients with SLE with a mean PWV of $6.1 \pm 1.7 \mathrm{~m} / \mathrm{s}^{8}$ In a newer study, participants were subdivided into two subgroups (brachial-ankle PWV (baPWV) $<14$ vs $>14 \mathrm{~m} / \mathrm{s}$ ). Nevertheless, the mean baPWV in all individuals was $15 \pm 0.38 \mathrm{~m} / \mathrm{s}^{9}$ Finally, Sacre et $a l^{10}$ reported a mean PWV of 
Table 1 Baseline characteristics of patients

\begin{tabular}{llllllll}
\hline & Age (years) & DOD (years) & SLE DAI & CFU-ECs $(\mathbf{n})$ & CD133+/FIk+ (\%) & PWV (m/s) & VAI \\
\hline Mean & 43.58 & 11.77 & 5.58 & 19.19 & 0.75 & 6.43 & 23.17 \\
SD & 15.34 & 8.88 & 4.34 & 19.57 & 0.48 & 1.74 & 13.36
\end{tabular}

CFU-ECs, colony-forming unit-endothelial cells; DAI, disease activity index; DOD, duration of diseases; PWV, pulse wave velocity; VAI, vascular augmentation index.
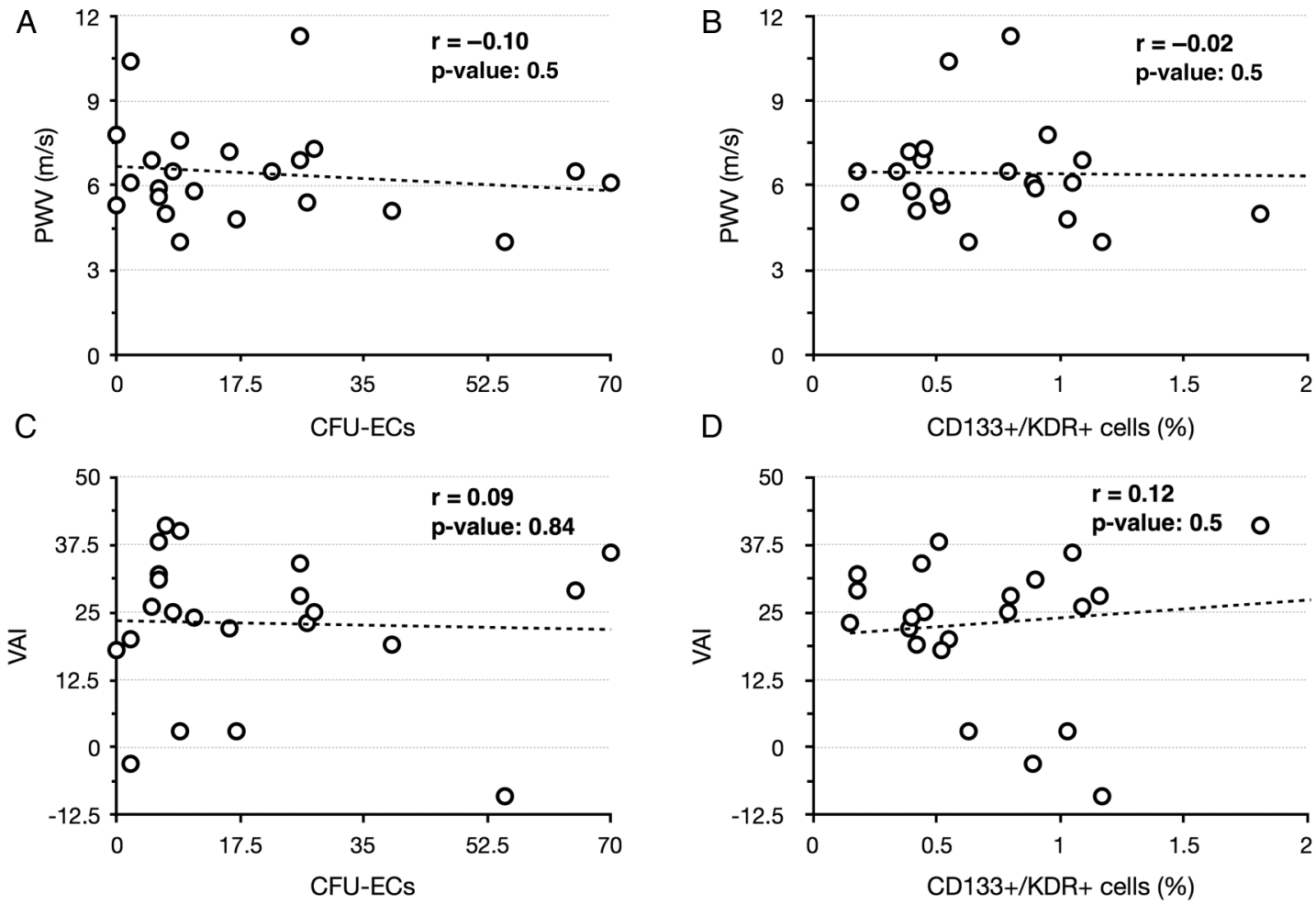

Figure 1 Correlation analysis between colony-forming unit-endothelial cells (CFU-ECs)/CD133+/KDR+ cells and pulse wave velocity $(\mathrm{PWV})$ /vascular augmentation index (VAI). Neither cell regeneration, as reflected by the number of colonies growing in culture, nor percentages of circulating CD133+/KDR+ cells correlated with PWV or VAI in a positive or negative manner.

$6.3 \pm 0.8 \mathrm{~m} / \mathrm{s}$. Therefore, our observation has two implications: the absolute PWV may significantly vary in SLE, most likely depending on the subjects investigated and the method used for PWV analysis. In addition, EPC colony formation/circulating EPCs may not reliably correlate with parameters of vascular stiffness. Thus, it can be questioned whether pulse wave analysis and/or EPC proliferation and circulating cell numbers are truly useful for cardiovascular risk assessment in SLE. Finally, it needs however to be mentioned that the current study was performed in an uncontrolled manner which may account for some limitations.

Contributors PK wrote the manuscript, DP assisted in manuscript writing and analysed data, EH performed EPC analyses, TBN corrected the manuscript, GAM supplied financial support and SP designed the study and recruited all patients.

Funding This work was supported by the Heidenreich von Siebold Programm.

Competing interests None.

Patient consent Obtained.
Ethics approval The study was approved by the local ethics committee of the Georg August-University Göttingen. All participants signed written consent.

Provenance and peer review Not commissioned; externally peer reviewed.

Data sharing statement All data are presented in the manuscript.

Open Access This is an Open Access article distributed in accordance with the Creative Commons Attribution Non Commercial (CC BY-NC 4.0) license, which permits others to distribute, remix, adapt, build upon this work noncommercially, and license their derivative works on different terms, provided the original work is properly cited and the use is non-commercial. See: http:// creativecommons.org/licenses/by-nc/4.0/

Acknowledgements Martha Potulski helped with initial studies.

\section{REFERENCES}

1. Hak AE, Karlson EW, Feskanich D, et al. Systemic lupus erythematosus and the risk of cardiovascular disease: results from the nurses' health study. Arthritis Rheum 2009;61:1396-402.

2. Patschan S, Patschan D, Potulski M, et al. Endothelial progenitor cells in systemic lupus erythematosus. J Nephrol 2013;26:1065-72.

3. Chirinos JA, Kips JG, Jacobs DR, et al. Arterial wave reflections and incident cardiovascular events and heart failure: MESA (Multiethnic Study of Atherosclerosis). J Am Coll Cardiol 2012;60:2170-7. 
4. Nichols WW, Edwards DG. Arterial elastance and wave reflection augmentation of systolic blood pressure: deleterious effects and implications for therapy. J Cardiovasc Pharmacol Ther 2001;6:5-21.

5. Vlachopoulos C, Xaplanteris P, Aboyans V, et al. The role of vascular biomarkers for primary and secondary prevention. A position paper from the European Society of Cardiology Working Group on peripheral circulation: endorsed by the Association for Research into Arterial Structure and Physiology (ARTERY) Society. Atherosclerosis 2015;241:507-32.

6. Castejon R, Jimenez-Ortiz C, Rosado S, et al. Metabolic syndrome is associated with decreased circulating endothelial progenitor cells and increased arterial stiffness in systemic lupus erythematosus. Lupus 2016;25:129-36.
7. Valero-Gonzalez S, Castejon R, Jimenez-Ortiz C, et al. Increased arterial stiffness is independently associated with metabolic syndrome and damage index in systemic lupus erythematosus patients. Scand J Rheumatol 2014;43:54-8.

8. Selzer F, Sutton-Tyrrell K, Fitzgerald S, et al. Vascular stiffness in women with systemic lupus erythematosus. Hypertension 2001;37:1075-82

9. Tso TK, Huang WN, Huang HY, et al. Association of brachial-ankle pulse wave velocity with cardiovascular risk factors in systemic lupus erythematosus. Lupus 2005;14:878-83.

10. Sacre K, Escoubet B, Pasquet B, et al. Increased arterial stiffness in systemic lupus erythematosus (SLE) patients at low risk for cardiovascular disease: a cross-sectional controlled study. PLOS ONE 2014;9:e94511. 